\title{
SINERGITAS DALAM PEMBINAAN DAN PENATAAN PEDAGANG KAKI LIMA (PKL) DI KOTA BANDUNG
}

\author{
Zaenal Abidin AS 1 \\ 1Prodi Ilmu Pemerintahan, Fakultas Ilmu Sosial dan Ilmu Politik \\ Universitas Jenderal Achmad Yani, Indonesia \\ e-mail: zaenal.abidin.as@lecture.unjani.ac.id
}

\begin{abstract}
Abstrak
Keberadaan pedagang kaki lima (PKL) di beberapa kota besar di Indonesia menimbulkan polemik yang sampai saat ini masih hangat di perbincangan, dimana keterkaitan ini dengan pola penataan ruang di suatu wilayah yang menimbulkan beberapa persoalan. Persoalan pkl bukan merupakan persoalan baru yang hanya ada di Indonesia bahkan di Amerika Latin dan Timur Tengah sendiri mengalami hal serupa, dan persoalan tempat-tempat mereka menjajakan jualan dan perijinan juga merupakan. Pola penanganan dengan mengedepankan sinergitas antara pemerintah dengan pihak lain dalam proses penanganan dapat menjawab persoalan-persoalan yang terkait dengan keberadaan pkl di suatu wilayah. Kota bandung sebagai kota metropolitan "Paris van java" yang menyediakan pusat-pusat perbelanjaan dan pusat wisata di tengah perkotaan. Tentunya hal ini tidak bisa menghindarkan kota bandung dari Keberadaan pkl. Sinergitas yang terjalin antara pemerintah dan para pkl dikota bandung menghasilkan beberapa inovasi diantaranya hari senin tanpa pkl, ide ini merupakan kepedulian para pkl terhadap kondisi kota bandung dengan keberadaan mereka yang kerap kali di tuding sebagai penyebab beberapa persoalan dan trobosan Pemerintah Kota Bandung yang sebelumnya tidak dilakukan di wilayah perkotaan Indonesia lainnya, Yaitu dibangunnya "Skywalk" di wilayah Cihampelas kota Bandung. Dimana skywalk diperuntukan sebagai sarana pejalankaki sekaligus berfungsi untuk menampung para pkl di sepanjang jalur wisata belanja Cihampelas.
\end{abstract}

Kata Kunci : Sinergitas dan Pedagang kaki Lima.

\begin{abstract}
The existence of street vendors (PKL) in several big cities in Indonesia has caused a polemic which is still hot in discussion, where this relationship with spatial planning patterns in an area is causing problems. The problem of street vendors is not a new problem that only exists in Indonesia, even in Latin America and the Middle East itself experiencing the same thing, and the problem of the places where they sell sales and licensing is also a problem. The handling pattern by prioritizing synergy between the government and other parties in the handling process can answer problems related to the existence of street vendors in an area. Bandung city as a metropolitan city "Paris van Java" which provides location centers and tourist centers in the city center. Of course, this cannot prevent the city of Bandung from being at street vendors. The synergy that exists between the government and street vendors in the city of Bandung
\end{abstract}


has resulted in several innovations including Monday without street vendors, this idea is the concern of street vendors for the condition of the city of Bandung with their existence who are often accused of being the cause of several problems and breakthroughs of the Bandung City Government that previously were not conducted in other urban areas in Indonesia, namely the construction of the "Skywalk" in the Cihampelas area of Bandung city. Where the skywalk is intended as a means of walking as well as serving to serve street vendors along the Cihampelas shopping route.

Keywords: Synergy and street vendors.

\section{PENDAHULUAN}

Persoalan Tataruang wilayah di perkotaan masih menjadi permasalahan yang dihadapi dalam mengembangkan potensi daerah, terbatasnya lahan dan padatnya mobilitas perkotaan menambah sulitnya proses penataan kota di dalam mempercepat pembangunan daerah. Keberadaan pedagang kaki lima (PKL) merupakan salahsatu kendala yang dihadapi oleh pemerintah didalam proses penataan wilayah, dimana keberadaan mereka dituding kerap kali menimbulkan beberapa persoalan, diantaranya adalah kemacetan, pengalihpungsian trotoar untuk pejalan kaki dan keindahan wilayah. Namun tidak dipungkiri disisi lain keberadaan mereka (PKL) memberika kontribusi didalam menambah pendapatan asli daerah (retribusi), tidak hanya itu keberadaan pkl di jalan malioboro justru memberikan ciri khas pariwisata untuk wilayah jogjakarta. Dengan kata lain keberadaan pkl di suatu wilayah dapat dikatakan sebagai potensi yang dimiliki oleh suatu daerah, namun hal ini memerlukan penanganan serius dari pemerintah daerah untuk mengelolanya sehingga tidak menimbulkan permasalahan-permasalahan yang justru menghambat proses pembangunan wilayah perkotaan.

Kemunculan Pedagang kaki lima (PKL) sendiri sudah terjadi sejak lama, dahulu kegiatan seperti ini disebut dengan istilah pedagang emperan. Dimana penyebutan pedagang kaki lima sekarang ini untuk mendeskripsikan para penjaja barang atau jasa yang menggunakan gerobak atau tidak dan berada dipinggiran jalan umum (trotoar). Bromley (dalam Manning. 1991) mendefinisikan pedagang kaki lima adalah salah satu pekerjaan yang paling nyata dan penting dikebanyakan kota di Afrika, Asia, Timur Tengah dan 
Amerika Latin. Pendapat lain yang mendefinisikan pedagang kaki lima adalah (Karafir, 1977) mengemukakan bahwa pedagang kaki lima adalah pedagang yang berjualan di suatu tempat umum seperti tepi jalan, taman-taman, emperemper toko dan pasar-pasar tanpa atau adanya izin usaha dari pemerintah. Dari dua definisi tentang pedagang kaki lima diatas menunjukan beberapa hal, diantaranya adalah persoalan pedagang kaki lima bukan merupakan persoalan baru yang hanya ada di indonesia bahkan di amerika latin dan timur tengah sendiri mengalami hal serupa, dan persoalan tempat-tempat mereka menjajakan jualan dan perijinan juga merupakan sebuah persoalan yang nyata didalam persoalan pedagang kaki lima.

Kota bandung merupakan kota metropolitan yang terletak di provinsi jawabarat terkenal sebagai kota mode "Paris van java" yang membuat kota bandung banyak menyediakan pusat-pusat perbelanjaan dan pusat wisata di tengah perkotaan. Tentunya hal ini tidak bisa menghindarkan kota bandung dari Keberadaan pkl, namun ada sesuatu yang menarik yang dapat kita kaji dari kota bandung dan pkl-nya yaitu adanya sinergitas yang terjalin antara pemerintah dan para pkl dikota bandung. Hal ini dapat kita lihat dari adanya kepedulian para pkl untuk mencetuskan hari senin tanpa pkl, tentunya penomena ini dapat kita maknai sebagai kepedulian para pkl terhadap kondisi kota bandung dengan keberadaan mereka yang kerap kali di tuding sebagai penyebab beberapa persoalan yang terjadi yang diakibatkan kemunculan mereka. Tidak hanya itu pemerintah kota bandung sebagai instansi pemerintah yang memiliki kewajiban untuk menyelesaikan persoalanpersoalan yang terjadi diwilayahnya melakukan trobosan yang sebelumnya tidak dilakukan di wilayah perkotaan indonesia, yaitu dengan dibangunnya "Skywalk" di wilayah cihampelas kota bandung. Dimana skywalk ini selain diperuntukan sebagai sarana pejalankaki, juga berfungsi untuk menampung para pedagang kaki lima di sepanjang jalur wisata belanja cihampelas.

Dari Kedua hal diatas peneliti menarik hipotesis awal, bahwa ada sebuah sinergisitas yang terjalin diantara pemerintah dan para Pkl didalam menghadapi sebuah persoalan-persoalan yang terjadi di kota bandung. 
Dimana hal ini dapat kita lihat dari terobosan-terobosan yang dilakukan oleh keduanya, dimana pkl sebagai salah satu objek penataan kota bandung memberikan sedikit solusi kepada pemerintah dengan di lakukannya deklarasi "Senin tanpa Pkl" dan kota bandung sebagai subjek dari penataan kota menjawab beberapa persoalan pkl dengan memberikan terobosan-terobosan yang peneliti anggap sebagai jawaban yang manusiawi didalam menghadapi sebuah persoalan perkotaan. Berangkat dari hal tersebut diatas peneliti beranggapan hal ini sangat menarik untuk di kaji, terutama berkaitan dengan sinergisitas penataan kota antara pemerintah dengan pkl. Dimana pemerintah kota bandung lewat Perda Kota Bandung No. 04 tahun 2011 tentang penataan dan pembinaan pedagang kaki lima, sudah mencanangkan bagaimana menjawab persoalan-persoalan yang dihadapi berkaitan dengan tataruang kota dan keberadaan pkl di kota bandung. Berdasarkan data Dinas Koperasi Perundustrian dan Perdagangan (Diskoperindag) tahun 2012 jumlah Pkl di Kota Bandung mencapai 20.326 Pkl yang tersebar di 30 kecamatan, namun jumlah tersebut mengalami peningkatan di tahun 2015 menjadi 22.359 pedagang. Dalam penelitian ini peneliti ingin mengetahui sejauh mana peran pemerintah kota bandung didalam melakukan pendekatan-pendekatan guna memanfaatan potensi yang dimilikinya (PKL) sehingga tidak menimbulkan persoalan-persoalan yang dapat menghambat dalam proses pembangunan dan tataruang wilayah perkotaan mengingat setiap waktunya jumlah pkl di kota bandung mengalami peningkatan, yang artinya ini menuntut adanya sinergisitas antara pemerintah da masyarakat pedagang didalam memangani permasalahan ini.

\section{METODE PENELITIAN}

Metode Penelitian ini menggunakan deskriptif dengan pendekatan kualitatif. Menurut Sugiyono (2012) mengatakan bahwa penelitian kualitatif adalah metode penelitian yang melandaskan pada filsafat postpositivisme, yang digunakan pada objek yang alamiah di mana peneliti adalah instrumen kunci. Hal ini senada dengan yang disampaikan oleh 
Moleong (2011) bahwa penelitian kualitatif adalah penelitian yang bermaksud memahami fenomena tentang apa yang dialami oleh subjek penelitian, misalnya perilaku, persepsi, motivasi, dan lainnya.

Unit analisis penelitian dari Elemen Pemerintahan kota bandung, yang dalam hal ini adalah instansi-instansi pemerintahan kota yang terkit dengan penataan dan pembinaan pedagang kaki lima (PKL) di kota bandung, seperti Dinas Tata Ruang Kota dan Satuan Polisi Pamong Praja (Satpol PP). dan unit analisis dari Elemen Masyarakat, yang meliputi pedagang kaki lima (PKL), Tokoh Masyarakat, Tokoh Pemuda, dan berbagai organisasi yang bergerak di bidang perekonomian dan keamanan lingkungan. Teknik pengumpulan data dilakukan dengan cara studi pustaka, observasi, wawancara, dan dokumentasi. Lokasi yang akan peneliti pilih sebagai tempat penelitian adalah pemerintah Kota bandung (Dinas Tataruang Kota, Dinas KUMKM, Polisi Pamong Praja (satpol PP), dan PKL yang berada di wilayah Balonggede, Cihampelas, Andir dan Cibaduyut Kabupaten bandung, Provinsi Jawa Barat.

\section{PEMBAHASAN}

Perkembangan Kota Bandung yang menjadi salah satu tujuan wisata di wilayah Jawa barat harus dapat menghadirkan kenyamanan dan kemanan bagi para wisatawan didalam melakukan segala aktifitas wisatanya di wilayah Kota Bandung. Pola Pembinaan dan penataan pedagang kaki lima (PKL) yang gagal akan membuat kesan tidak nyaman bagi para wisatawan, namun jika pola pembinaan dan penataan Pkl berhasil dilakukan oleh kota bandung akan menghasilkan tempat wisata yang nyaman dan tidak mustahil dapat menghadirkan tempat wisata baru yang di tawarkan di Kota Bandung. Penataan sepanjang jalan Malioboro di Kota Jogjakarta dapat menjadi barometer keberhasilan pembinaan dan penataan pkl di Indonesia, dan membuat wilayah ini menjadi salah satu destinasi unggulan yang wajib di kunjungi ketika berada di Kota Jogjakarta.

Pola penanganan Pkl bukan merupakan persoalan yang mudah untuk di wujudkan, dimana ketika pemerintah mengeluarkan sebuah kebijakan tanpa 
solusi tentu hal ini akan mengakibatkan kesan diskriminatif bagi para pelaku ekonomi non formal ini (Pkl). Dimana hal ini dapat dilihat bahwa pola relokasi yang selama ini dilakukan oleh pemerintah tidak dapat menjawab persoalan keberadaan mereka di suatu tempat. Namun jika pemerintah kemudian tidak mengeluarkan dan memberikan pembinaan dan penataan terhadap keberadaan mereka hal ini akan berimbas kepada sector-sektor yang lain (Kemacetan dan kesemerawutan tata Kota). Penanganan dengan melibatkan semua pihak perlu dilakukan pemerintah sebagai pembuat dan pelaksana kebijakan di lapangan, dimana dengan adanya pola sinergitas antara pemerintah dengan pihak-pihak lain akan menghadirkan win-win solution yang jika dilakukan oleh pemerintah sendiri sulit untuk dilakukan. Pola sinergitas sendiri dapat dilakukan dengan koordinasi dan komunikasi yang terjalin baik antara pemerintah dan seluruh unsur yang terlibat didalam munculnya pedagang kaki lima di Kota Bandung.

\section{Komunikasi dan Koordinasi}

Komunikasi dan koordinasi merupakan salah satu hal yang dapat dilakukan dalam proses pelaksanaan sinergitas, dimana komunikasi dapat membangun sebuah keselarasan antar lembaga/Instansi. Komunikasi yang dibangun dengan baik dan berkelanjutan akan menghasilkan sebuah data dan informasi yang diperlukan dalam menangani dan menanggapi sebuah permasalahan. Komunikasi dan koordinasi yang dilakukan oleh pemerintah Kota Bandung dalam hal pembinaan dan penataan keberadaan PKL yang berada di wilayah Kota Bandung dapat dilakukan dengan berbagai pihak, baik dengan pihak sektoral di lingkungan pemerintahan Kota Bandung, maupun dengan LSM yang berkecimpung dengan permasalahan penataan dan pembinaan PKL di Kota Bandung atau dengan tokoh masyarakat sendiri, dan dengan pelaku PKL sendiri.

Komunikasi dan koordinasi selalu di lakukan oleh pemerintah Kota bandung didalam melakukan pembinaan dan penataan Pkl di Kota Bandung, 
hal ini sesuai dengan hasil wawancara dengan dinas penataan ruang kota bandung di bawah ini :

"Kami selalu melakukan komunikasi dengan beberapa pihak, hal ini dilakukan untuk membicarakan beberapa permasalahan yang di hadapi Kota bandung terutama permasalahan Pkl. Hasil dari komunikasi yang kita lakukan kemudian kami jadikan sebagai acuan awal didalam membuat strategi pembinaan dan penataan yang terkait dengan keberadaan pkl di Kota Bandung."

Hal yang sama juga di kemukakan oleh kepala Dinas KUMKM Kota bandung yang terkait dengan pembinaan dan penataan Pkl di Kota Bandung, hal ini dapat dilihat dari hasil wawancara berikut ini :

"Dinas Koperasi UMKM Kota Bandung bersama dengan SKPD terkait diantaranya, Satpol PP, Bappelitbang, dan dinas tataruang akan terus membina para Pkl , demi kenyamanan tata ruang Kota Bandung. Hasil yang kami dapatkan dari Komunikasi yang dilakukan diantaranya adalah proses pembinaan dalam bentuk pencetakan kartu tanda pengenal bagi para Pkl yang berjualan di Zona Kuning dan Zona Hijau dan melakukan koordinasi pada tempat pusat perbelanjaan."

Pernyataan serupa dikemukakan oleh Kepala Satpol PP Kota Bandung, dimana hal ini di kemukakan dari hasil wawancara berikut ini :

"Komunikasi terkait tentang pembinaan dan penataan Pkl di kota bandung sudah dilakukan dengan baik oleh pemerintah dengan beberapa SSPD dan pihak-pihak lain yang terkait. Satpol PP sebagai bagian dari proses pelaksana pengawasan dan Pengendalian, secara terus menerus melakukan komunikasi dan koordinasi di setiap wilayah yang di tempati Pkl, semua ini dilakukan agar penataan lebih baik, sehingga lokasinya di tempati oleh Pkl menjadi lebih Baik.” 
Dari beberapa hasil wawancara diatas, dapat dikatakan bahwa proses komunikasi dan koordinasi antar pemerintah dengan SKPD Kota Bandung sudah dapat di katakana berjalan dengan baik, dimana hal ini menghasilkan beberapa strategi didalam proses pembinaan dan penataan Pkl di kota Bandung. Dimana dari hasil komunikasi yang dilakukan diatas diantaranya adalah dibuatkannya Zonanisasi (zona Merah, Zona Kuning dan Zona Hijau), dikeluarkannya kartu tanda pengenal bagi Pkl yang berada di Kota bandung. Dari beberapa hal yang dihasilkan dari komunikasi yang dijalin oleh pemerintah dan dengan SKPD terkait, tentu hal ini akan dapat mewujudkan penataan ruang wilayah yang baik di Kota Bandung.

Pemerintah Kota Bandung terus melakukan pendekatan terhadap pedagang Kaki Lima (PKL) guna dapat melaksanakan penataan dan pembinaan Pkl di wilayah Kota Bandung. Pelaksanaan Perda No 4 Tahun 2011 tentang Penataan dan Pembinaan Pedagang Kaki Lima di kota bandung diwujudkan dengan membentuk satuan tugas khusus penataan dan pembinaan PKL (Satkassus PKL), yang terdiri dari berbagai Satuan Kerja Perangkat Daerah (SKPD) dan bekerja sesuai dengan wewenangnya masingmasing. Dimana hal ini juga di kemukakan oleh Kepala bidang usaha nonformal dinas KUMKM Kota Bandung berikut ini : "proses penataan PKL tidak serta langsung di tertibkan, melainkan melalui berbagao proses yang dijalankan."

Selain komunikasi yang dilakukan dengan SKPD, pemerintah Kota Bandung juga melakukan komunikasi dengan beberapa PKL dan tokoh masyarakat, hal ini juga di benarkan oleh ketua Asosiasi Pekerja dan Pedagang kaki Lima (APPKL) Kota Bandung. Hal ini dapat dilihat dari hasil wawancara berikut ini :

"Kami selaku perkumpulan masyarakat dan PKL yang berada di wilayah Kota Bandung sangat apresiasi dengan pemerintah, dimana kami selalu di berikan kesempatan untuk melakukan komunikasi dan koordinasi dengan Pemerintah (wali Kota). Dimana minimal sebulan sekali kami di 
undang ke pendopo rumah dinas wali kota untuk membicarakan permasalahan-permasalahan yang terkait dengan PKL di Kota Bandung."

Hal serupa juga di kemukakan oleh beberapa perwakilan pedagang yang berada di wilayah Kota Bandung, hal ini dapat di lihat dari beberapa hasil wawancara berikut ini :

Hasil wawancara dengan pedagang kaki lima di wilayah Cibaduyut :

"Dalam proses pelaksanaan kegiatan PKL di wilayah ini kami di koodrinir oleh pak $\mathrm{Rw}$, dimana setiap ada persoalan-persoalan yang berkaitan dengan keberadaan kami, kami selalu di kumpulkan dan membicarakannya bersama-sama". (Pedagang Mie ayam di kawasan Sentara Cibaduyut).

"Dari awal keberadaan kami di sini, kami selalu berkoordinasi dengan kepala RW. Baik dari mulai permusyawarahan sampai kami di tata ulang seperti ini, dan kami juga suka di ajak berkomunikasi dan berkoordinasi dengan Appkl Kota Bandung dan beberapa dinas Kota Bandung”.(pedagang di kawasan kuliner wisata Balongan Kota Bandung).

Proses Komunikasi yang dilakukan oleh pemerintah Kota Bandung Beserta SKPD terkait sudah dilakukan dengan baik, dimana dari hasil wawancara dan observasi yang dilakukan peneliti, dimana peneliti dapat memberikan kesimpulan terkait dengan proses komunikasi yang dilakukan pemerintah, SKPD, LSM PKL (APPKL) dengan beberapa temuan peneliti yang terkait dengan proses pembinaan dan penataan Pkl di Kota bandung, diantaranya adalah :

1. Dibentuknya satuan tugas khusus penataan dan pembinaan PKL (Satkassus PKL), yang terdiri dari berbagai Satuan Kerja Perangkat Daerah (SKPD) dan bekerja sesuai dengan wewenangnya masing-masing.

2. Pendataan yang dilakukan oleh Badan perencanaan pembangunan penelitian dan pengembangan (Bappelitbang) yang di lakukan pada tahun 
2015, dimana ada 22.359 Pkl yang terdata, dimana jumlah tersebut tersebar di 30 Kecamatan yang berada di wilayah Kota Bandung.

3. Diterapkannya regulasi mengenai zonasi bagi Pkl di kota Bandung Oleh Dinas Penataan Ruang, dimana dinas penataan ruang menetapkan Zona Merah sebagai wilayah yang terlarang bagi keberadaan Pkl. Dimana Zona Merah ini diantaranya adalah jalan provinsi, Jalan nasional, Rumah Ibadah, Rumah sakit dan Komplek Militer. Sedangkan Zona Kuning adalah wilayah yang di bolehkan untuk Pkl melakukan kegiatannya, namun hanya waktu tertentu dan sifatnya sementara, dan Zona Hijau adalah wilayah yang memang di peruntukan bagi Pkl untuk melakukan kegiatannya.

4. Pembinaan yang dilakukan oleh Dinas Koperasi dan UMKM, dimana didalam peroses pembinaan ini dilakukan dengan dua jenis, diantaranya adalah : pembinaan dalam hal pemberdayaan dan pengembangan, dan pembinaan dalam hal fasilitasi dan Pembiayaan.

5. Proses pengawasan, pengendalian dan penindakan dilakukan oleh satuan Polisi pamong praja (satpol PP), dimana Satpol PP yang di berikan kewenangan dan tanggungjawab dalam hal perumusan sepek hokum. Selain itu satpol PP juga yang akan memberikan Advokasi danpendampingan hokum, pelaksanaan dan pengendalian, dan penindakan terhadap pelanggaran-pelanggaran yang terjadi di lapangan.

\section{Hambatan-hambatan yang dihadapi dalam Pembinaan dan penataan PKL di Kota Bandung}

Pelaksanaan pembinaan dan penataan Pkl di Kota Bandung juga dihadapkan dari beberapa persoalan, dimana didalam fakta di lapangan ditemukan beberapa hambatan yang di hadapi, salahsatunya adalah :

1. Jumlah Pkl yang setiap tahun bertambah, berdasarkan data tahun 2015 jumlah pkl di kota bandung mencapai 22 ribu, dimana angka tersebut terus bertambag Setiap Tahunnya (pikiran-rakyat.com). 
2. Tidak tersedianya lahan bagi para pedagang, dimana hal ini yang menyulitkan pemerintah didalam melaksanakan relokasi pkl di Kota Bandung.

3. Tidak tersedianya lahan parkir yang memadai, dimana keberadaan Pkl juga di perparah dengan adanya parkir liar di beberapa lokasi.

\section{Strategi yang di hasilkan dari proses Sinergitas Pemerintah Kota Bandung}

Dari hasil komunikasi dan koordinasi yang dilakukan oleh pemerintah beserta dengan SKPD dan PKL ini menghasilkan beberapa gagasan yang di sepakati bersama, diantaranya adalah dengan digagasnya hari senin tanpa PKL. Dimana gagasan ini lahir dari pemerintah Kota bandung melalui wakil wali kota Bandung yang mengadakan komunikasi dan koordinasi beserta PKL di beberapa wilayah yang tersebar di Kota Bandung. Dimana wilayah-wilayah ini yang selama ini masuk kedalam kategori darurat macet, gagasan ini di sepakati bersama antar pemerintah dan PKL. Dimana disepakati bersama bahwa setiap hari Senin PKL akan libur dari kegiatan perekonomiannya, hal ini berangkat dari alasan bahwa hari pertama masuk kerja dan sekolah di setiap minggu ini dijadikan sebagai hari libur. Sangat di sadari oleh PKL bahwa kebijakan ini dapat membuat kegiatan perekonomian mereka terganggu, dan tentu akan membuat kerugian buat mereka. Namun hal ini dapat di sepakati bersama dan di laksanakan bersama demi terciptanya penataan kota dan pembinaan PKL di Kota Bandung. Proses pengawasan tentang program senin tanpa PKL sendiri tidak hanya di lakukan pengawasan oleh Satpol PP, namun proses pengawasan ini juga dilakukan antar para PKL sendiri.

Dari strategi-yang di lakukan oleh pemerintah Kota Bandung, di hasilkan beberapa gagasan. Diantaranya adalah :

1. Dibuatkannya jalur satu arah seperti yah di berlakukan di wilayah wisata kuliner Balonggede, dimana di wilayah itu Pkl di bentuk satu bagian saja (sebelah kanan saja). Dan arus kendaraan hanya di fungsikan sebagai jalur satu arah. 
2. Dibuatkannya skywalk di cimampelas, dibuatkannya teras cihampelas adalah inovasi yang digagas pemerintah kota bandung didalam melaksanakan pembinaan dan penataan pkl di Kota Bandung.

3. Diberlakukannya hari senin tanpa $\mathrm{Pkl}$, dimana kegiatan ini di bentuk untuk mengantisipasi kegiatan pertama perkantoran dan anak sekolah. Dimana dari kegiatan ini memiliki dampak yang cukup membantu didalam mengurai kemacetan yang sering terjadi di beberapa wilayah.

\section{KESIMPULAN}

Proses pelaksanaan pembinaan dan penataan Pkl di Kota Bandung dapat di katakana sudah berjalan dengan baik, hal ini dapat di lihat dari proses sinergitas yang dilakukan dengan baik antara pemerintah, Lembaga Masyarakat dan pelaku pedagang kaki lima (ekonomi non formal). Dengan konsep komunikasi dan koordinasi yang dijalin antar mereka dapat dilihat dari beberapa kegiatan dan inovasi yang di keluarkan oleh pemerintah dan Pkl, diantaranya adalah :

1. Dikeluarkannya zonasi yang menentukan wilayah-wilayah yang boleh dan tidak boleh dijadikan sebagai tempat Pkl melakukan kegiatan perekonomian non formalnya.

2. Diberlakukannya hari senin tanpa $\mathrm{Pkl}$, dimana ide ini di gagas oleh pemerintah lewat wakil walikota bersama dengan beberapa pandangan dari Lsm dan pelaku Pkl. Sehingga hal ini berdampak positif terhadap mengurai permasalahan kemacetan yang terjadi di beberapa wilayah di Kota bandung, kegiatan ini menjadi inovasi baru yang di laksanakan oleh pemerintah dan di sambut baik oleh para Pkl. Dimana didalam proses pengawasannya tidak hanya pemerintah (Satpol PP) namun juga antar para pelaku Pkl juga saling mengawasi sesamanya.

3. Di bangunnya Skywalk di Cihampelas dan di berlakukannya arus kendaraan satu arah di wilayah Balonggede, dapat memberikan nuansa baru dalam proses penanganan dan penataan Pkl di Kota Bandung dan berdampak kepada terciptanya destinasi wisata baru di Kota Bandung. 
4. Pendataan para Pkl dengan di buktikan dengan dikeluarkannya kartu tanda pengenal Pkl di Kota Bandung yang di keluarkan Oleh dinas Koperasi dan UMK Kota bandung merupakan salah satu wujud dari proses pelaksanaan penataan dan pembinaan $\mathrm{Pkl}$ di Kota Bandung, dimana hal ini dapat mempermudah pemerintah didalam proses relokasi dan penyaluran bantuan kredit kepada setiap Pkl. Harapan yang akan di ambil dari proses ini supaya para pelaku Pkl dapat bertransformasi menjadi sector ekonomi yang tadinta Non-formal menjadi sector ekonomi formal, atau paling tidak dapat sedikit menggeser paradigma negative yang berkembang karena keberadaan Pkl di Kota Bandung.

Meskin proses komunikasi dan koordinasi yang dilakukan oleh pemerintah Kota Bandung Sudah dilakukan dengan baik, namun masih di temukan beberapa permasalahan yang kemudian menjadi penghambat didalam proses pembinaan dan penataan Pkl Di Kota Bandung. Salah satunya adalah peningkatan jumlah Pkl yang sanagt signifikan di setiap tahunnya, dan juga timbulnya masalah baru yang di timbulkan dari inovasi atau kebijakan yang di keluarkan oleh pemerintah. Misalnya saja pembangunan Skywalk di daerah Cihampelas, persoalan relokasi Pkl memang sudah terjawab, namun proses mengurai kemacetan di wilayah ini masih tetap terjadi. Hal ini di karenakan kurangnya lahan parkir yang di sediakan, baik oleh pemerintah maupun oleh pemilik toko di sepanjang jalan Cihampelas. Sehingga peneliti didalam proses memberikan saran dapat di jelaskan melalui penjelasan beriku ini :

1. Adanya atauran yang mewajibkan setiap pusat perbelanjaan menyediakan lahan parkir, sehingga hal ini juga dapat dijadikan sebagai proses mengembalikan fungsi trotoar sesuai dengan peruntukannya.

2. Penataan kembali julmlah Pkl di Kota Bandung, dari data yang di miliki oleh pemerintah tersebut dijadikan sebagai dara awal didalam proses penataan dan pembinaan Pkl. Sehingga ada progress apa yang harus dilakukan oleh pemerintah didalam mengangkat profesi Pkl menjadi sector ekonomi Formal. Karena yang peneliti lihat, kebijakan tentang 
relokasi tidak berbanding lurus dengan semangat Pkl dan banyak di temukan proses relokasi yang bermasalah. Masalah yang di hadapi pemerintah bukan hanya bentokan dengan Pkl namun juga dalam proses relokasi, yang mana tidak semua Pkl tidak dapat menikmati Lokasi rekolasi yang di sediakan oleh pemerintah dan akhirnya mereka hanya bias menyewa kios yang sebenarnya diperuntukan untuk mereka.

3. Data-data yang di miliki oleh pemerintah, yang terkait dengan $\mathrm{Pkl}$ dijadikan sebagai pegangan untuk mendorong $\mathrm{Pkl}$ menjadi satu golongan yang mandiri. Dengan kata lain Lsm yang bergerak di bidang Pkl ini harus di kuasai dan dijalankan oleh para Pkl sendiri, sehingga kebijakan-kebijakan yang nantinya akan di jadikan pemerintah sebagai data awal didalam membuat kebijakan akan menjadi tepat sasaran.

\section{DAFTAR PUSTAKA}

Agus Salim. 200, Teori dan Paradigma Penelitian Sosial, Yogyakarta, Tiara Wacana.

Charles Hamped Tuner, 1990, Charting the corporate mind: from dilemma to strategy. Oxford: Basil Blackwell.

Chris manning dan Tadjuddin Noer Effendi. 1991. Urbanisasi, Pengangguran dan Sektor Informal di Kota, Jakarta: Yayasan Obor Indonesia.

2001. Urbanisasi, Pengangguran dan Sektor Informal di Kota, Jakarta: Yayasan Obor Indonesia.

Damsar. 2009. engantar Sosiologi Ekonomi. Jakarta: Kencana

Drs. H. Malayu, S.P. Hasibuan, 2007. Manajemen Sumber Daya Manusia. Jakarta : Cetakan 9. PT. Bumi Aksara.

Edi, Suharto. 2008. Kebijakan Sosial Sebagai Kebijakan Publik. Bandung: Alfabeta

Hanafi hartanto, 1996. Keluarga berencana dan kontrasepsi. Pustaka sinar harapan, jakarta.

Hani T. Handoko. 2003. Manajemen. Cetakan Kedelapanbelas. BPFEYogyakarta, Yogyakarta

Hidayat, 2007. Peranan, Profil dan Prospek Pedagang Eceran (Formal dan Informal) dalam Pembangunan, Prisma, bulan Juli. 
Karafir dkk, 1977. Pemupukan Modal Pedagang Kaki Lima, Seri Pernerbitan Fakultas Ilmu-ilmu Sosial, UI, Jakarta.

Lexy Moleong, J. 2007, Metode Penelitian Kualitatif, Bandung, PT. Remaja Rosdakarya.

Mark L. Sirower, 1998. The Synergy Trap. Penerbit PT Gramedia Pustaka Utama, Jakarta.

Moekijat. 1994. Dasar-Dasar Motivasi. Bandung: Subur Bandung.

Peter Senge. (1990). Fifth discipline. New York: Doubleday.

T. Ramli. 2003. Pendidikan Karakter. Bandung : Angkasa

Sofyandi dan Garniwa. 2007. Perilaku Organisasional. Edisi Pertama. Yogyakarta: Graha Ilmu.

Ulber, Silalahi. (2011). Asas - Asas Manajemen. Bandung: Refika Aditama

Warren G. Bennis \& Patricia W. Biederman, 1997 Organizing Genius: The Secrets of Creative Colloboration (Hardcover). HarperCollins Canada / Perseus Books.

Dokumen Lain :

Hasil Konsep Lokakarya, Pengaturan, Pemberdayaan dan Pembinaan Pedagang Kaki Lima di Kota Bandung. Kerjasama Kadinda Kota Bandung dan Pemkot Bandung. 1999.

Profil Kota Bandung 2015

Kota Bandung Dalam Angka 2017.

www. Pikiran-Rakyat.com 